\title{
Democracia, um exercício de modéstia ${ }^{1}$
}

Às vezes, por falta de algo melhor (naturalmente, no metrô), reflito sobre a democracia. Sabe-se que há uma atribulação nos espíritos no que se refere a essa noção tão útil. E, como gosto de travar conhecimento com o maior número de homens possível, procuro as definições que poderiam ser aceitáveis para a grande maioria. Não é coisa fácil e não me gabo de ter obtido sucesso. Mas acho que se pode chegar a algumas aproximações úteis. Para ser breve, eis uma delas: a democracia é o exercício político e social da modéstia. Resta explicá-la.

Conheço duas espécies de raciocínios reacionários. (Já que é necessário precisar tudo, convenhamos em chamar de reacionárias todas as atitudes que visam a aumentar indefinidamente as servidões políticas e econômicas que pesam sobre os homens.) Estes dois raciocínios seguem em direções opostas, mas têm por característica comum a expressão de uma certeza absoluta. O primeiro consiste em dizer: "Nunca se modificará nada nos homens". Conclusão - as guerras são inevitáveis, a servidão social está na natureza das coisas, deixemos que os fuzileiros fuzilem e cuidemos do nosso jardim (na verdade, geralmente se trata de um parque). O outro consiste em dizer: "É possível mudar os homens. Mas sua liberação depende de tal fator e é preciso agir de tal maneira para lhes fazer o bem." Conclusão - é lógico oprimir: $1^{\circ}$ aqueles que acreditam que não há mudança possível; $2^{\circ}$ aqueles que não concordam a respeitodo fator; $3^{\circ}$ aqueles que, mesmo concordando sobre o fator, não concordam com os meios destinados a modificá-lo; $4^{\circ}$ todos aqueles, em geral, que pensam que as coisas não são assim tão simples.

Ao todo, três quartos da humanidade.

Nos dois casos, encontramo-nos diante de uma simplificação obstinada do problema. Nos dois casos, introduz-se na problemática social uma fixidez ou um determinismo absoluto que não lhe são compatíveis. Nos dois casos, sente-se suficientemente convicto para fazer ou deixar fazer a história, segundo seus princípios, e para justificar ou agravar a dor humana. Estes espíritos, tão diferentes, mas cuja própria convicção perdura apesar das demais, estou de acordo que se lhes admire. Mas é preciso pelo menos lhes chamar por seus nomes e dizer o que eles são e o que não são capazes de fazer. Eu digo, por minha parte, que são espíritos orgulhosos e que podem alcançar tudo, exceto a liberação humana e

\footnotetext{
${ }^{1}$ CAMUS, Albert. La Démocracie exercise de la modestie. In: CAMUS, Albert. Essais. Paris: Éditions Gallimard et Calmann-Lévy, 1965. Tradução de Francisco Amsterdan Duarte da Silva. Este artigo foi originalmente publicado por Camus na revista Caliban, $\mathrm{n}^{\circ}$ 20, em novembro de 1948.
} 
uma democracia real. Há uma frase que Simone Weil teve a coragem de escrever e à qual, por sua vida e por sua morte, soube fazer jus: "Quem pode admirar Alexandre de toda sua alma se não tiver a alma pequena?" Sim, quem pode equiparar as maiores conquistas da razão ou da força aos imensos sofrimentos que elas representam, a não ser que tenha um coração cego à mais simples empatia e um espírito desviado de toda justiça!

Por isso me parece que a democracia, seja ela social ou política, não pode ser baseada numa filosofia política que pretenda tudo saber e tudo resolver, da mesma forma que ela não pôde ser fundamentada até hoje por uma moral de conservação absoluta. A democracia não é o melhor dos regimes; é o menos ruim. Provamos um pouco de cada regime e agora sabemos disto. Este regime, porém, só pode ser concebido, criado e sustentado por homens que sabem que não sabem de tudo, que se recusam a aceitar a condição proletária e que nunca se acomodam diante da miséria dos outros, mas que também recusam, precisamente, agravar essa miséria em nome de uma teoria ou de um messianismo cego.

O reacionário do antigo regime defendia que a razão não resolvia nada. $O$ reacionário do novo regime pensa que a razão resolverá tudo. $\mathrm{O}$ verdadeiro democrata acredita que a razão pode iluminar um grande número de problemas e até mesmo solucionar alguns. Mas ele não acredita que ela reine, senhora absoluta, sobre o mundo inteiro. $\mathrm{O}$ resultado é que o democrata é modesto. Ele confessa uma parcela de ignorância, ele admite o caráter em parte aventuroso de seu empenho e que nem tudo está ao seu alcance. E, a partir dessa confissão, ele admite ter necessidade de consultar os outros, de complementar o que sabe com aquilo que eles sabem. Ele só se reconhece como, por direito, delegado pelos outros e submisso ao seu acordo contínuo. Qualquer que seja a decisão que ele é levado a tomar, ele admite que os outros, por quem a decisão foi tomada, possam julgá-la de outra forma e deixálo a par. Já que os sindicatos são feitos para defender os proletários, ele sabe que são os sindicalizados que, pelo confronto de suas opiniões, têm a maior chance de adotar a melhor tática.

A verdadeira democracia refere-se sempre à base, pois ela supõe que nenhuma verdade, neste âmbito, é absoluta e que várias experiências humanas, somadas umas às outras, representam uma verdade aproximativa mais preciosa do que uma doutrina coerenteporém falsa. A democracia não defende uma ideia abstrata, nem uma filosofia brilhante; ela defende os democratas, o que implica lhes convidar a decidir sobre os meios mais adequados a assegurar a própria defesa.

\begin{tabular}{|l|l|l|l|l|}
\hline Qovista Dialectus & Ano 5 & n.13 & Agosto - Dezembro 2018 & p. 245 - 247 \\
\hline
\end{tabular}


Sei muito bem que uma concepção tão prudente não passa sem perigo. Sei muito bem que a maioria pode se enganar ao mesmo tempo em que a minoria vê claramente. É por isso que digo que a democracia não é o melhor regime. Mas deve-se pôr na balança os perigos dessa concepção e os que resultam de uma filosofia política que tudo coage. Dada a experiência, é melhor aceitar uma ligeira perda de velocidade do que se deixar arrastar por uma torrente furiosa. De resto, a mesma modéstia supõe que a minoria possa se fazer ouvir e que se leve em conta seus pontos de vista. É por isso que digo que a democracia é o menos ruim dos regimes.

Daí não se segue que tudo está resolvido. É neste sentido que essa definição não é definitiva. Ela permite examinar, no entanto, sob uma luz precisa, os problemas que nos cabem e cujo princípio remete à ideia de revolução e à noção de violência. Ela permite ainda recusar ao dinheiro e à polícia o direito de chamar de democracia aquilo que não é. Somos alimentados com mentiras, ao longo do dia, por uma imprensa que é a vergonha deste país. Todo pensamento, toda definição que arrisque aumentar essas mentiras ou sustentá-las é, hoje, imperdoável. Basta dizer que ao definir certo número de palavras-chaves, ao torná-las suficientemente claras hoje para que amanhã elas sejam eficazes, nós trabalhamos pela liberação e cumprimos nosso papel.

Albert Camus.

Caliban, novembro de 1948.

\begin{tabular}{|l|l|l|l|l|}
\hline Qonista Dialectus & Ano 5 & n.13 & Agosto - Dezembro 2018 & p. $245-247$ \\
\hline
\end{tabular}

